\title{
Investigation of chronic diarrhoea in acquired immunodeficiency syndrome. A prospective study of 155 patients
}

\author{
C Blanshard, N Francis, B G Gazzard
}

\begin{abstract}
Background and Aims-The optimum diagnostic investigation for patients with acquired immunodeficiency syndrome (AIDS) and diarrhoea is not known. Often no pathogen is detected and it is unclear whether this is because pathogens are absent in some patients or the investigations used fail to detect them. The hypothesis that AIDS related diarrhoea is usually due to an infection, which can be identified by a simple diagnostic strategy based on the results of intensive investigation of a cohort of such patients, was investigated.
\end{abstract}

Methods-155 patients with AIDS and chronic diarrhoea underwent contemporaneous examination of stools, duodenal, jejunal, and rectal biopsy specimens and duodenal aspirate for bacterial, protozoal, and viral pathogens. A decision tree analysis was used to determine the best sequential diagnostic strategy for clinicians. Results-128 of 155 patients investigated $(83 \%)$ had at least one potential pathogen. The presenting clinical features could not predict the presence or site of the pathogens. Stool analysis identified the most pathogens (93 of 199, 47\%). Rectal biopsy was essential for the diagnosis of cytomegalovirus and adenovirus. Duodenal biopsy was as helpful as jejunal biopsy and detected some treatable pathogens missed by other methods. Electron microscopy, impression smears, and duodenal aspirate yielded little extra information. If gut biopsy was reserved for patients without a stool pathogen, some treatable pathogens would have been missed.

Conclusion-Most patients with AIDS and chronic diarrhoea have at least one gut pathogen, which can be identified by stool analysis and light microscopic examination of duodenal and rectal biopsies. Some pathogens will be missed unless all these investigations are done on all such patients.

(Gut 1996; 39: 824-832)

Keywords: diarrhoea, investigation, human immunodeficiency virus, acquired immunodeficiency syndrome, diagnosis, decision analysis.

A variety of opportunistic and non-opportunistic pathogens may cause diarrhoea in patients infected with the human immunodeficiency virus (HIV), and some patients have no pathogen identified even after extensive gastroenterological investigations. ${ }^{1-15}$ It is unclear whether this is because known pathogens are genuinely absent or because the investigations performed lack sensitivity. Several algorithms have been proposed to investigate HIV related diarrhoea, with the aim of identifying all pathogens or detecting treatable pathogens at least cost. In 1990, Johanson and Sonnenberg ${ }^{16}$ wrote an influential paper in which a medical decision analysis suggested that the most cost effective way of alleviating the diarrhoea in a cohort of 1000 theoretical patients was to perform a single stool culture, with specific treatment for those patients with an identifiable bacterial pathogen and symptomatic treatment with diphenoxylate for the rest.

However, this model is no longer applicable. The authors assumed that diarrhoea would resolve in $67 \%$ of patients treated with diphenoxylate, regardless of the cause, based on a small uncontrolled study of patients with cryptosporidial diarrhoea. ${ }^{17}$ It was also assumed that there was no effective treatment available for CMV colitis, which is no longer true. ${ }^{18-22}$ Furthermore the prevalence of infections may have changed as microsporidia have become more widely recognised. The accurate identification of the causes of diarrhoea in HIV positive patients allows appropriate treatment and counselling about the prognosis, as well as entry into trials of new potential treatments. However, performing extensive investigations on all patients is expensive, time consuming, and potentially uncomfortable for the patient. It is not known which of the currently available investigations are the most useful or the order in which they should be carried out. We have therefore prospectively studied a large cohort of AIDS patients with chronic diarrhoea to see how many have pathogens and discover if the results of an intensive investigation protocol can be used to construct guidelines for the investigation of diarrhoea in such patients.

\section{Methods}

PATIENTS

The aim of the study was to enrol all patients presenting over a two year period with a CD4 
lymphocyte count of less than 200 cells/ $\mu$ l and uninvestigated diarrhoea for at least four weeks (defined as the passage of at least three liquid or semi-liquid stools daily on at least five days of each week). Patients were recruited from a hospital HIV Clinic, two hospital Genitourinary Medicine clinics, and hospital inpatients. All the staff working with HIV seropositive patients in the clinics and on the wards were made aware of the aims and design of the study and encouraged to refer patients. In addition there was an open meeting for patients and their carers at which the investigation and management of diarrhoea was discussed, and a notice about the study appeared in the 'Body Positive' newsletter, which is widely read by HIV infected subjects. Regular verbal and written reminders were circulated.

\section{Completeness of case ascertainment}

The completeness of case ascertainment was checked to exclude the possibility of referral bias in the cohort. This was done in three ways.

(1) A record was kept of patients referred who did not attend for appointments or investigation or who did not complete investigations were noted.

(2) A computer search was made to identify those patients not included in the cohort presenting with a known cause of chronic diarrhoea presenting during the study period; those with a diagnosis of 'diarrhoea for more than a month, no cause found', and those with wasting syndrome (weight loss of greater than $10 \%$ of normal body weight with diarrhoea or fever and weakness for more than a month).

(3) Pharmacy records were used to identify those patients who had received more than a month's supply of antidiarrhoeal drugs.

For all the above patients not included in the cohort the notes were reviewed to ascertain whether they fitted the inclusion criteria.

\section{INITIAL ASSESSMENT}

All patients were assessed by one author (CB) and a standardised clinical history taken. A full physical examination was performed including fundoscopy.

Blood was drawn for the following investigations if they had not been performed during the past two weeks: full blood count, CD4 count, serum urea and electrolytes, liver enzymes, protein, albumin, bilirubin, calcium, phosphate, vitamin B12, folate, red cell folate, blood glucose.

Patients were advised to bring three stool specimens with them by the referring member of staff (one from the previous morning, one from the previous evening, and one from that morning). These were labelled and transported to the laboratory, and containers were issued for a further three specimens to be brought at the next visit. The study was explained to participants and informed consent obtained.
ENDOSCOPIES

Sigmoidoscopy and endoscopy were performed within seven days of initial assessment, whether or not a potential pathogen was identified in the initial three stool specimens.

All of the endoscopies were done by one author (CB), using an Olympus GIFQ20 or GFXQ20 endoscope and intravenous sedation with midazolam in a dose titrated to produce drowsiness. The oesophagus and stomach were examined and biopsy specimens taken of any macroscopic abnormality. The endoscope was then passed into the duodenum and duodenal fluid aspirated into a sterile container after discarding the first 2-3 ml. Eight pinch biopsy specimens were taken from random sites in the distal second part of the duodenum and immediately placed in fixative or used to make impression smears.

Providing the procedure had been well tolerated a Watson capsule was then mounted on the endoscope, which was introduced a second time. The capsule was passed out of sight into the jejunum, air aspirated from the intestine, and the knife mechanism fired. The biopsy specimen was oriented on card and divided into three unequal portions, the larger for light microscopy, a small portion for electron microscopy, and a smear was made with the remainder.

Sigmodoscopy was performed while the patient remained sedated, using a rigid plastic disposable sigmoidoscope. Biopsy specimens were taken from any areas of macroscopic abnormality or from three random sites.

\section{HISTOPATHOLOGY}

Impression smears were made from two duodenal biopsy specimens and part of the jejunal biopsy sample by holding them in fine forceps, allowing to dry for a few seconds, dabbing lightly several times on one end of a clean dry microscope slide, and then drawing the specimen across the slide several times to make a smear one cell thick. Four to five slides were prepared for each biopsy specimen. The smears were air dried and fixed for one to two minutes in absolute methanol, then stained in $10 \%$ Giemsa for 35 minutes, and examined under oil immersion $(\times 1000)$.

A total of four duodenal biopsy specimens, part of the jejunal biopsy sample, and the rectal biopsy specimens were fixed in $10 \%$ formyl saline for at least three hours. The fixed specimens were dehydrated through graded ethanols, cleared, and embedded in paraffin wax. Sections 1-5 $\mu \mathrm{m}$ thick were cut using a rotary microtome, placed on glycerine albumin coated slides and heated on a hotplate for 15 minutes. After dewaxing and dehydrating in xylene and methanol the slides were washed in tap water and stained with haematoxylin and eosin, periodic acid Schiff (PAS), PAS-diastase, and Ziehl-Neelsen stains. At least two levels per block were examined. 
Immunohistochemistry

Immunoperoxidase staining for CMV was done on all rectal and duodenal biopsy specimens as well as any gastric and oesophageal specimens obtained from areas of abnormality. Sections $3.5 \mu \mathrm{m}$ thick were cut from two different levels, dewaxed, and treated with trypsin for 12 minutes. A mouse monoclonal antibody (Dako M757) was used as the CMV primary antibody at a dilution of 1 in 30 and incubated for two hours at room temperature in a humidified chamber. After washing, biotinylated rabbit antimouse was applied for 30 minutes at a dilution of 1 in 500 . Avidin-biotin complex $(1 \mu \mathrm{l}$ each in $25 \mu \mathrm{l})$ was applied for 30 minutes, washed, and developed with diaminobenzidine. ${ }^{23}$

Immunohistochemical staining for adenovirus was carried out on the rectal biopsy specimens using adenovirus primary antibody (Serotec No MCA 489) at a dilution of 1 in 1000 . Sections were mounted on poly-l-lysine coated slides, subjected to 15 minutes protease digestion, and incubated with primary antibody for one hour. Secondary antibody and avidin-biotin complex were incubated for one hour each and, after washing, developed with diaminobenzidine for five minutes. ${ }^{24}$

\section{Electron microscopy}

Two duodenal biopsy specimens and part of the jejunal biopsy sample were fixed in 3\% glutaraldehyde in 0.1 molar cacodylate buffer $(\mathrm{pH} 7 \cdot 3)$ for between six and 12 hours at $4^{\circ} \mathrm{C}$. After washing they were cut into 1-2 mm cubes, post-fixed in $1 \%$ osmium tetroxide, dehydrated through graded methanols and block stained with uranyl acetate, impregnated with propylene oxide, and embedded in Taab resin. The specimens were oriented villi upwards under the dissecting microscope during embedding. Sections $70 \mathrm{~nm}$ thick were stained with uranyl acetate and lead citrate and examined using a JEOL 100 CX microscope.

\section{MICROBIOLOGY}

Stool specimens were cultured for faecal pathogens on Salmonella/Shigella agar medium, Campylobacter selective medium, and Selanite $\mathrm{F}$ enrichment medium. Concentrated wet preparations were examined by direct microscopy for ova cysts and parasites. Smears were stained with auramine for cryptosporidia: if positive the diagnosis was confirmed by a modified acid-fast method. Ziehl-Neelsen stained smears were examined for acid-fast bacilli and specimens were inoculated onto Lowenstein-Jensen slopes and cultured for mycobacteria. The slopes were examined weekly for eight weeks and if colonies were observed Ziehl-Neelsen staining was used to confirm that they were mycobacteria. Concentrated preparations were prepared and examined for cryptosporidia if six auramine stained smears were negative and diarrhoea persisted.
A tissue culture cytotoxicity assay for Clostridium difficile toxin B was performed on one stool sample, using the neutralised, buffered supernatant of a $20 \%$ stool suspension inoculated into human foreskin fibroblast cultures. A positive test was the presence of a cytopathic effect at 24-48 hours, neutralised by $\mathrm{Cl}$ sordelli antitoxin (Wellcome Ltd, Dartford, UK).

Blood cultures for mycobacteria and other pathogens were obtained from all febrile patients using a $\mathrm{C} 14$ radiometric assay (Bactec; Becton Dickinson Diagnostic Instrument Systems Ltd, Tucson, Maryland, USA).

\section{VIROLOGY}

Stool specimens from all patients were tested for rotavirus antigen using a commercial rotavirus latex agglutination test (Wellcogen, Wellcome, Dartford, UK) and if positive the diagnosis was confirmed by electron microscopy. Those from all patients recruited after November 1991 were examined for viral particles using electron microscopy. A $10 \%$ suspension of the stools was made in phosphate buffered saline and cleared by low speed centrifugation. The supernatant was then ultracentrifuged and the pellet stained with $2 \%$ phosphotungstic acid ( $\mathrm{pH}$ 7) and examined with the electron microscope. These patients also had part of their rectal biopsy specimen processed for electron microscopy and examined for viral particles.

\section{OTHER INVESTIGATIONS}

Further investigations were done as clinically indicated. Although tests of malabsorption were not part of the investigation protocol many of the cohort had xylose absorption tests and Schilling tests (using the double radiolabelled Dicopac method) as part of the routine investigation of weight loss and these data are included where appropriate.

FOLLOW UP

One patient was lost to follow up immediately after investigation. The remainder were reviewed regularly until the diarrhoea settled or until death or for a minimum of six months (median follow up nine months, range two weeks-30 months). Those whose diarrhoea resolved were returned to the care of their primary physician but advised to reattend if the symptoms recurred.

Further investigation in patients with persisting 'pathogen negative' diarrhoea

All patients who had persistent diarrhoea and negative initial investigations had further investigations as follows:

(1) Six further stool specimens were sent for stool culture and microscopy as before.

(2) Three stool specimens were examined by electron microscopy for viral particles and tested for rotavirus using a latex test. 
(3) Colonoscopy was carried out following bowel preparation with 'Klean-Prep' (Norgine, Headington, Oxford, UK). Patients were sedated with midazolam and pethidine and the colonoscope was advanced proximally to the caecum. Serial biopsy specimens (three from each of terminal ileum (if possible), ascending colon, transverse colon, descending colon, and rectosigmoid) were obtained for light and electron microscopy.

(4) The upper gastrointestinal endoscopy was repeated with biopsies and duodenal aspiration as before.

(5) A double contrast (per os) barium study of the small bowel was performed.

DATA RECORDING AND ANALYSIS

A case record form was kept for each patient and the data entered into a computer using SPSS Data Entry. Data analysis was done using SPSS (SPSS Inc, Chicago, Illinois).

To determine whether features in the history, examination or basic haematological and biochemical tests could be used to distinguish between patients who did and did not have a pathogen, a number of features in these two groups were compared by univariate analysis, using the Students' $t$ test for normally distributed numerical variables such as CD4 count or stool frequency, the Mann-Whitney test for non-normally distributed variables such as serum folate, and the $\chi^{2}$ test (with Yates's correction if the expected values in any cell were less than 5) for categorical variables such as the presence of abdominal pain. The baseline clinical findings were further analysed in the same way to determine any significant differences between patients with small and large bowel pathogens.

To identify the best sequence of investigations a decision tree analysis was used in which the initial choice of investigations was analysis of one, three or six stools, followed by duodenal or rectal biopsy specimen or both if no pathogen was found in the stools (Fig 1). The analysis was repeated for 'definite' and treatable pathogens, as defined by consensus view in the current literature. The probabilities at each chance node were calculated directly from the results of the study.

\section{Results}

Between 1 August 1990 and 31 July 1992, 2086 patients with HIV infection attended the unit, of whom 887 had an AIDS defining opportunistic infection or malignancy and 1019 had a CD4 lymphocyte count persistently below $200 / \mu 1$. A total of 155 patients meeting the inclusion criteria $(15 \%$ of those with a CD4 count of less than $200 / \mu \mathrm{l}$ ) were recruited and completed investigations. Most (91\%) were primary (self) referrals with a smaller number of referrals from local general practitioners or other hospitals.

A further 20 patients fitted the inclusion criteria but were not included in the study: five patients did not wish to participate, two failed to attend for investigation, and nine were not referred because they had a diagnosis made by another physician (including six patients with cryptosporidiosis and two with both cryptosporidium and CMV infection). Two patients tolerated endoscopy poorly so that biopsy specimens could not be obtained and two patients were too ill for further investigations or died before investigations were complete.

The characteristics of the cohort are given in Table I and were very similar to that of the clinic population in general, except $151(97 \%)$ were homosexual or bisexual men, compared with $81 \%$ of the clinic population. $\left(\chi^{2}=24 \cdot 5\right.$, $\mathrm{p}<0.0001$ ).

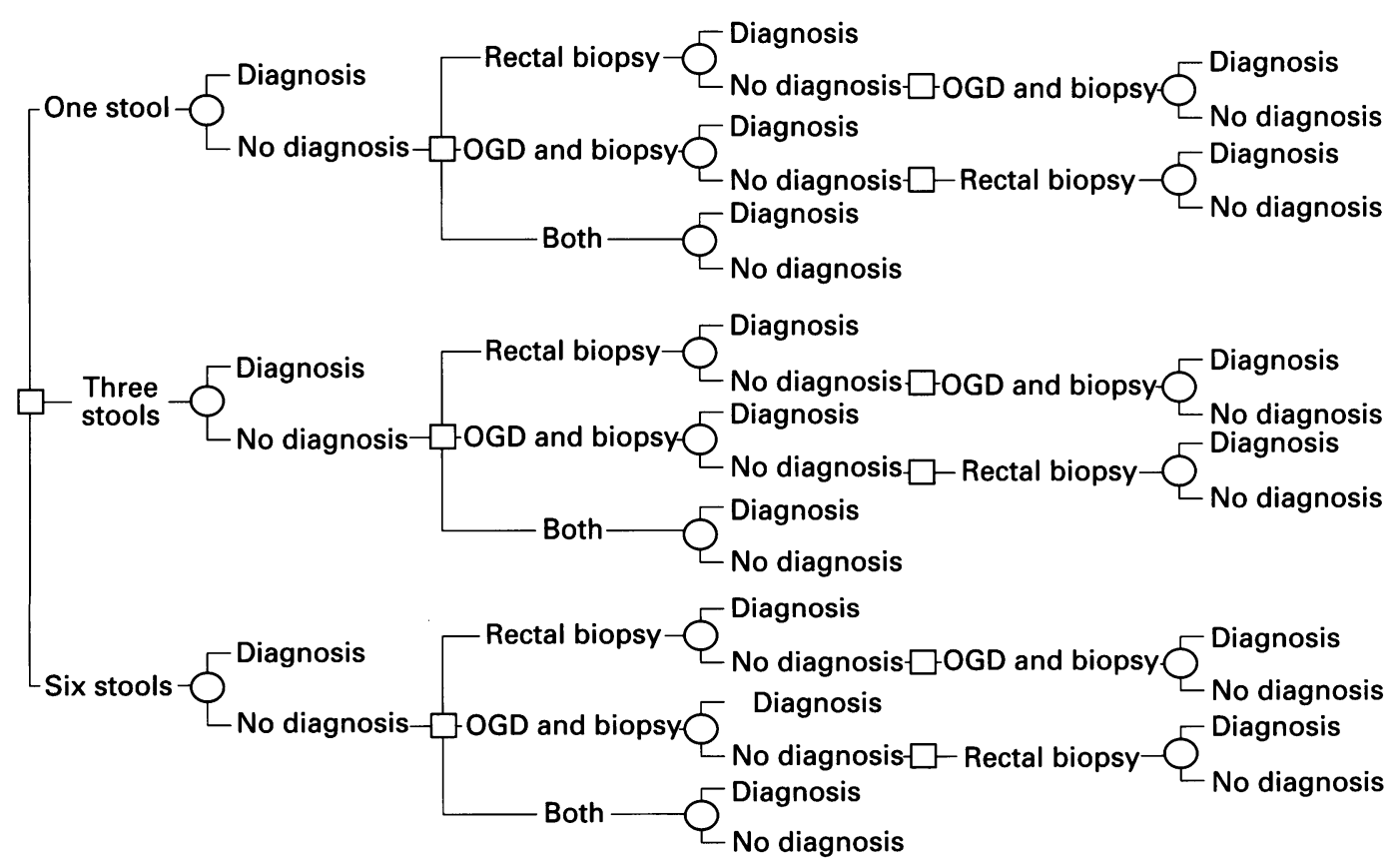

Figure 1: Decision tree for the diagnosis of HIV related chronic diarrhoea. The squares are decision nodes and the circles chance nodes. The probability at each chance node was calculated directly from the study data. 
TABLE I Characteristics of the cohort of 155 patients investigated

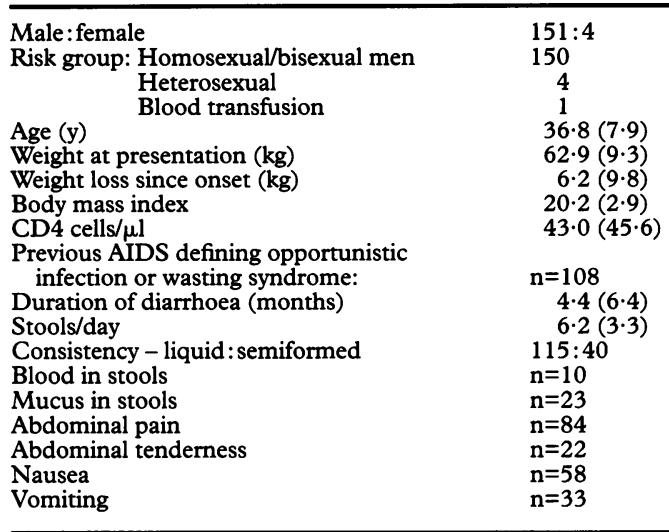

Age, weight, weight loss body mass index, duration of diarrhoea and stool frequency are given as mean (SD).

Some 128 patients $(83 \%)$ had at least one potential cause of diarrhoea identified after completing investigations, including 46 (30\%) with more than one (Table II).

\section{FINDINGS AT UPPER GASTROINTESTINAL} ENDOSCOPY

Two patients had CMV ulcers in the oesophagus and two had CMV gastritis. Eleven had non-specific gastritis or gastric ulceration and seven had duodenal ulcers or duodenitis. Five patients had Kaposi's sarcoma of the upper gastrointestinal tract and 24 patients had candidal oesophagitis.

Twenty five patients had 'velvety' or 'cobblestoned' duodenal mucosa all of whom had a small bowel pathogen (microsporidia in 22, MAI in two, and cryptosporidia in one).

TABLE II Pathogens and potential pathogens identified in the cohort of 155 patients after completing the investigation protocol (The numbers indicate the number of patients with each pathogen)

\begin{tabular}{lc}
\hline Untreatable definite pathogens & \\
Cryptosporidium & 47 \\
Microsporidium (E bieneusi) & 37 \\
Treatable definite pathogens & \\
Mycobacterium avium intracellulare & 12 \\
Cytomegalovirus & $29 \dagger$ \\
Giardia & 18 \\
Salmonella & 2 \\
Shigella & 1 \\
Campylobacter & 7 \\
Toxigenic Clostridium difficile & 2 \\
Isospora & 1 \\
Microsporidium (Septata intestinalis) & 1 \\
Untreatable possible pathogens & \\
Adenovirus & 10 \\
Rotavirus & 2 \\
Coronavirus & 3 \\
Small round virus & 3 \\
Treatable possible pathogens & \\
Blastocystis hominis & 6 \\
Spirochaetes & 7 \\
Entamoeba histolytica & 2 \\
Staphylococcus aureus (in duodenal aspirate) & 1 \\
Psuedomonas sp (in duodenal aspirate) & 1 \\
Invasive duodenal Candida & 1 \\
Non-infectious causes & \\
Radiation proctitis & 1 \\
Crohn's disease & 1 \\
Extensive small bowel KS & 1 \\
Small bowel lymphoma & 2 \\
\hline
\end{tabular}

By consensus view in the literature. $\nmid$ In addition six patients had CMV infection of the oesophagus or stomach only. $\mathrm{KS}=$ Kaposi's syndrome.
SIGMOIDOSCOPIC FINDINGS

Evidence of proctitis with contact bleeding or superficial ulceration was found in 17 of the patients, 12 of whom had CMV inclusions on biopsy.

\section{INVESTIGATION RESULTS}

Some pathogens were identified by only one investigation, others by more than one. No investigation had $100 \%$ sensitivity for the identification of any pathogen (Table III).

\section{Stool analysis}

Stool analysis identified more pathogens (93 of $199,47 \%$ ) than any other investigation. The diagnostic yield increased as up to six specimens were examined. In seven of 47 cases of cryptosporidiosis the organisms were identified in biopsy specimens when the stools were persistently negative (Fig 2).

\section{Small bowel biopsy}

Duodenal biopsy alone identified 87 potential pathogens in 77 patients. Watson capsule jejunal biopsy specimens were successful in 111 patients and gave an identical pathological diagnosis in all but two cases, both of whom had pathogens seen only on duodenal pinch biopsy specimens.

When compared with light microscopy, electron microscopy missed one case of giardia infection, one of microsporidia, one of MAI, three of small bowel cryptosporidiosis, and all but one of the cases of small bowel CMV. No additional pathogens were found at electron microscopy.

Nine small bowel protozoal infections diagnosed by other means were not seen in touch preparations of duodenal biopsy material (five cryptosporidia, one giardia, and three microsporidia), but one case of microsporidiosis and one of giardiasis were found that were not identified by any other diagnostic method.

\section{Duodenal aspirate}

Duodenal aspirate had a low overall sensitivity when compared with duodenal biopsy but detected one case of giardiasis not diagnosed by any other method.

\section{Rectal biopsy}

Rectal biopsies identified 65 potential causes of diarrhoea in 52 patients. Only 17 of the biopsy specimens were histologically normal, the remainder showing a diffuse infiltrate of chronic inflammatory cells even in the absence of a specific pathogen. Eight biopsy specimens showed Melanosis coli. This was always associated with a pathogen (microsporidiosis in six, CMV and adenovirus in one and, cryptosporidiosis in one.

The diagnostic yield of some of these investigations is summarised in Figures 3-5. 
TABLE III Diagnostic yield of various investigations

\begin{tabular}{|c|c|c|c|}
\hline Investigation & $\begin{array}{l}\text { Total pathogens } \\
\text { identified (\%) }\end{array}$ & Pathogens found & Pathogens missed \\
\hline One stool & $37(18 \cdot 6)$ & $\begin{array}{l}\text { cryptosporidium (18) } \\
\text { blastocystis (3) } \\
\text { entamoeba (2) } \\
\text { giardia (3) } \\
\text { salmonella (1) } \\
\text { campylobacter (2) } \\
\text { MAI (4) } \\
\text { rotavirus (1) } \\
\text { adenovirus (1) } \\
\text { coronavirus (1) } \\
\text { small round virus (1) }\end{array}$ & $\begin{array}{l}\text { cryptosporidium (29) } \\
\text { blastocystis (3) } \\
\text { giardia (15) } \\
\text { isospora (1) } \\
\text { salmonella (1) } \\
\text { shigella (1) } \\
\text { campylobacter (5) } \\
\text { MAI (8) } \\
\text { Cl difficile (2) } \\
\text { rotavirus (1) } \\
\text { adenovirus (9) } \\
\text { coronavirus (2) } \\
\text { small round virus (2) }\end{array}$ \\
\hline Three stools & $77(38 \cdot 7)$ & $\begin{array}{l}\text { cryptosporidium (32) } \\
\text { blastocystis (5) } \\
\text { entamoeba (2) } \\
\text { giardia (9) } \\
\text { salmonella (1) } \\
\text { shigella }(1) \\
\text { campylobacter (7) } \\
\text { MAI (9) } \\
\text { Cl difficile (1) } \\
\text { rotavirus (2) } \\
\text { adenovirus (4) } \\
\text { coronavirus (2) } \\
\text { small round virus (2) }\end{array}$ & $\begin{array}{l}\text { cryptosporidium (15) } \\
\text { blastocystis (1) } \\
\text { giardia (9) } \\
\text { isospora (1) } \\
\text { salmonella (1) } \\
\text { MAI (3) } \\
\text { Cl difficile (1) } \\
\text { adenovirus (6) } \\
\text { coronavirus (1) } \\
\text { small round virus (1) }\end{array}$ \\
\hline Six stools & $93(46 \cdot 7)$ & $\begin{array}{l}\text { cryptosporidium (39) } \\
\text { blastocystis (6) } \\
\text { entamoeba (2) } \\
\text { giardia }(10) \\
\text { salmonella (1) } \\
\text { shigella }(1) \\
\text { campylobacter (7) } \\
\text { MAI (10) } \\
\text { Cl difficile (2) } \\
\text { rotavirus (2) } \\
\text { adenovirus (5) } \\
\text { coronavirus (3) } \\
\text { small round virus (3) }\end{array}$ & $\begin{array}{l}\text { cryptosporidium (8) } \\
\text { giardia (8) } \\
\text { isospora (1) } \\
\text { salmonella (1) } \\
\text { MAI (2) } \\
\text { adenovirus (5) }\end{array}$ \\
\hline Blood culture & $7(3 \cdot 5)$ & $\begin{array}{l}\text { MAI (4) } \\
\text { salmonella }(1) \\
\text { shigella }(1) \\
\text { strep viridans (1) }\end{array}$ & $\begin{array}{l}\text { MAI (8) } \\
\text { salmonella (1) }\end{array}$ \\
\hline Rectal biopsy & $65(32 \cdot 7)$ & $\begin{array}{l}\text { cryptosporidia (24) } \\
\text { CMV (25) } \\
\text { adenovirus (9) } \\
\text { spirochaetes (7) } \\
\text { radiation proctitis (1) }\end{array}$ & $\begin{array}{l}\text { cryptosporidia (23) } \\
\text { CMV (4) } \\
\text { adenovirus (1) }\end{array}$ \\
\hline Duodenal biopsy & $87(43 \cdot 7)$ & $\begin{array}{l}\text { cryptosporidia (23) } \\
\text { microsporidia (37) } \\
\text { giardia (11) } \\
\text { isospora (1) } \\
\text { CMV (8) } \\
\text { MAI (6) } \\
\text { candidiasis (1) }\end{array}$ & $\begin{array}{l}\text { cryptosporidia (24) } \\
\text { microsporidia (1) } \\
\text { giardia (7) } \\
\text { CMV (21) } \\
\text { MAI (6) }\end{array}$ \\
\hline $\begin{array}{l}\text { Jejunal biopsy } \\
\text { (in } 111 \text { patients with } \\
142 \text { pathogens) }\end{array}$ & $54(38)$ & $\begin{array}{l}\text { cryptosporidium (16) } \\
\text { microsporidium (27) } \\
\text { isospora (1) } \\
\text { giardia (3) } \\
\text { MAI (3) } \\
\text { CMV (4) }\end{array}$ & cryptosporidium (1) \\
\hline $\begin{array}{l}\text { Touch preparation } \\
\text { (in } 135 \text { patients with } \\
170 \text { pathogens) }\end{array}$ & $49(28 \cdot 8)$ & $\begin{array}{l}\text { microsporidia }(33) \\
\text { cryptosporidia (10) } \\
\text { giardia (9) }\end{array}$ & $\begin{array}{l}\text { microsporidia (3) } \\
\text { cryptosporidium (5) } \\
\text { giardia (1) }\end{array}$ \\
\hline Duodenal aspirate & $12(6 \cdot 1)$ & $\begin{array}{l}\text { cryptosporidia (4) } \\
\text { giardia (4) } \\
\text { isospora (1) } \\
\text { MAI (1) } \\
\text { pseudomonas (1) } \\
\text { staph aureus (1) }\end{array}$ & $\begin{array}{l}\text { cryptosporidia (19) } \\
\text { giardia (7) } \\
\text { MAI (6) }\end{array}$ \\
\hline
\end{tabular}

In 'pathogens found' and 'pathogens missed' the numerals in parentheses refer to the number of cases. ${ }^{\star}$ Includes one patient with $S$ intestinalis. For jejunal biopsy, touch preparation, and duodenal aspirate the 'pathogens missed' is by comparison to duodenal biopsy. not helpful in predicting whether a pathogen might be identified except that abdominal tenderness was significantly commoner in patients with CMV infection than in those with any other diagnosis $\left(\chi^{2}=23.9, \quad p=\right.$ $0.00001)$. Surprisingly, weight loss of more than $5 \mathrm{~kg}$ or positive malabsorption tests were not correlated with the presence of a small bowel pathogen (compared with a large bowel pathogen or no pathogen) although high stool volume was (Table V). Nor was patient reported blood and mucus in the stool correlated with the presence of a large bowel pathogen.

\section{Decision tree analysis}

A sequential approach, stopping once the first pathogen is identified, results in a number of pathogens, including treatable ones, being missed. (Table VI).

We have repeated the analysis, assuming that examination of six stools would also have $100 \%$ sensitivity for the diagnosis of microsporidiosis. This investigation was not routinely available when this study was started but has since been suggested to have an excellent sensitivity and specificity. ${ }^{25}{ }^{26}$ If rectal biopsy and stool analysis was performed on all patients $82 \%$ of all pathogens would be identified (missing some cases of giardia MAI and isospora, CMV duodenitis, pathogenic bacteria in duodenal aspirates, and the small bowel malignancies). If rectal biopsy was done only in those patients with negative stools, and duodenal biopsy in those with negative stools and rectal biopsy specimens, the diagnostic yield would be $71 \%$.

\section{Discussion}

A number of previous publications have suggested algorithms for the investigation of diarrhoea in HIV seropositive patients, ${ }^{10} 11131627-31$ but no study has attempted to assess the utility of the proposed investigations in clinical practice. We present the results of a large prospective study of chronic diarrhoea in AIDS patients. We chose to study patients with a CD4 count of less than $200 / \mu l$ and diarrhoea for more than a month as our previous studies have shown that most pathogens occur in this patient group. ${ }^{32}$ The study population contained a greater proportion of homosexual men than the clinic population from which it was derived. This may be because the homosexual population have more advanced disease, reflecting the changing epidemiological pattern of AIDS in the United Kingdom; in addition homosexual men may have a higher incidence of gut pathogens. However we see no reason why the conclusions of the study could not be extrapolated to other Western populations.

The key feature of the investigation protocol was that stool analysis, small bowel and large bowel biopsy were performed on all patients to maximise the chance of identifying all pathogens in multiply infected patients and produce accurate prevalence figures for the
Patients who had a cause of diarrhoea identified had a significantly lower mean CD4 cell count, a lower mean weight at presentation, and had lost on average more weight than those without a pathogen (Table IV). The history and examination findings were 


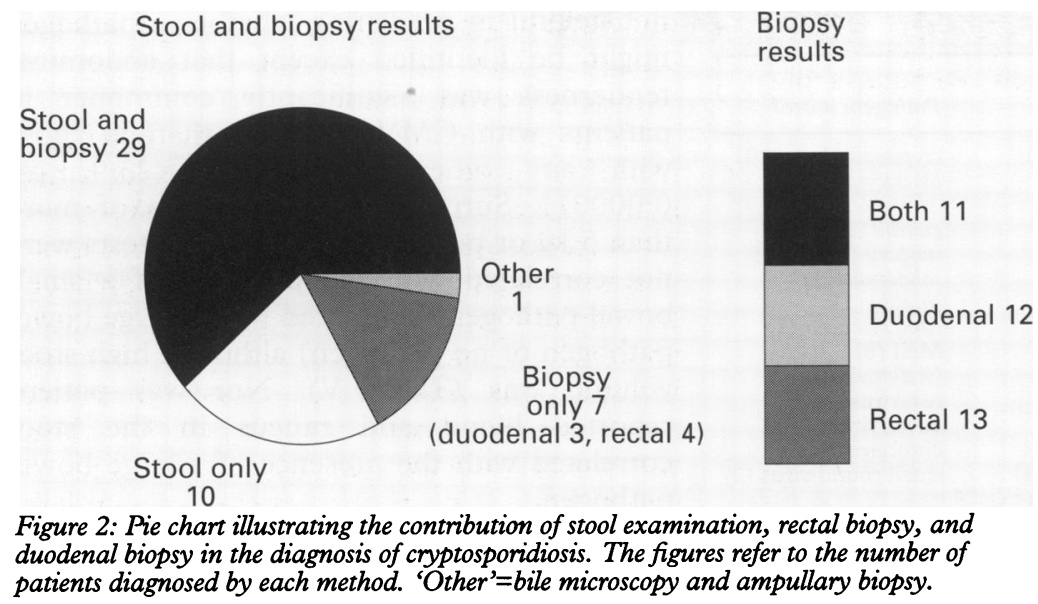

different infections. The high rate of multiple infections $(29 \%)$ compared with some series may be due to this approach. The identification of such multiple infections is important not only to explain treatment failures but because the elimination of a second treatable pathogen may result in improvement of the diarrhoea or even disappearance of the untreatable pathogen. ${ }^{33}$

This is the first study to give a true indicator of the prevalence of microsporidiosis in unselected AIDS patients with chronic diarrhoea, as most previous series have looked for microsporidia only in patients in whom other pathogens have been excluded. ${ }^{34} 35$

Although there were significant differences in CD4 counts, stool volumes, the rate of weight loss, and vitamin B12 values between patients with and without a pathogen there was a large overlap and such clinical features could not be used to identify those patients most likely to have a pathogen. Nor could the site of the pathogen be predicted accurately by features in the history and examination. These findings together with the high prevalence of pathogens suggest that all patients should be offered investigation.
Stool analysis is sensitive and non-invasive. The sensitivity increases considerably between one and three samples, particularly for the detection of cryptosporidia, but only slightly for subsequent samples. However in eight patients with cryptosporidiosis, organisms were persistently absent from the stools but present on gut biopsy.

Rectal biopsy is the only reliable way to diagnose CMV and adenovirus proctocolitis and rigid sigmoidoscopy is easily performed in the gastroenterology outpatient clinic. There has been concern that CMV infection may be confined to the right side of the colon in up to $30 \%$ of cases $^{20}$ but we identified CMV on colonoscopy after initially negative rectal biopsies in only two cases. However colonoscopy was performed only on the 35 patients with initially negative investigations.

The most common pathogens primarily infect the small bowel and so biopsy of the duodenum has a high diagnostic yield with some cases of cryptosporidiosis, giardiasis, MAI, CMV being diagnosed only by this method. Jejunal biopsy has no advantage. Characteristic histological changes in the duodenum of patients with MAI are strongly suggestive that the organism may be the cause of the diarrhoea whereas culture of it from the stool may only indicate colonisation. The diagnostic utility of duodenal biopsy will be reduced but not eliminated if the new stool methods for the diagnosis of microsporidia are as sensitive and specific as biopsy.

Although in some series ${ }^{36}$ duodenal aspirate, obtained via nasoduodenal intubation, has been sensitive in the diagnosis of small bowel pathogens we have not found this to be the case, perhaps due to the lower incidence of small bowel parasites in this series or the different technique used. In expert hands impression smears have a high diagnostic yield for protozoal pathogens particularly microsporidia but we found them difficult to prepare and they added little extra sensitivity to

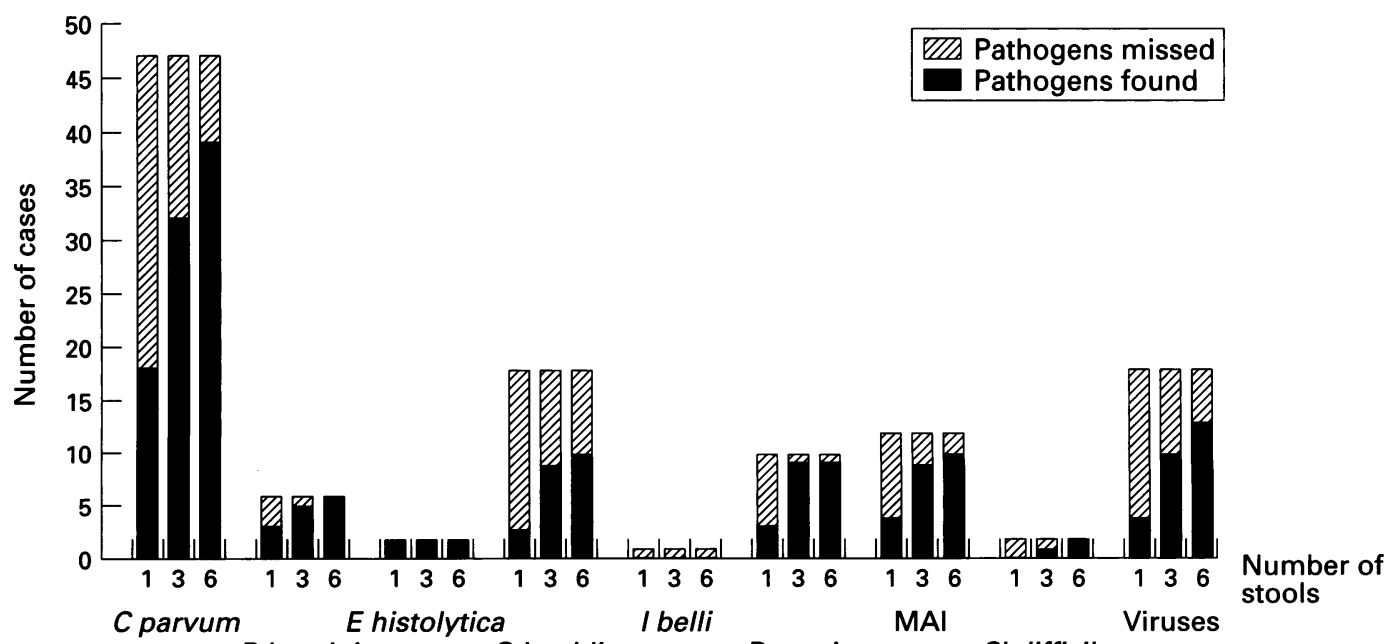

$B$ hominis

G lamblia

Bacteria

Cl difficile

Figure 3: Histogram summarising the results of stool examination of duodenal biopsy specimens in the diagnosis of various pathogens. The total height of the bars show the number of patients with each pathogen and the heavily shaded portion the number detected by the method. The results of one, three, and six stools are shown separately. 


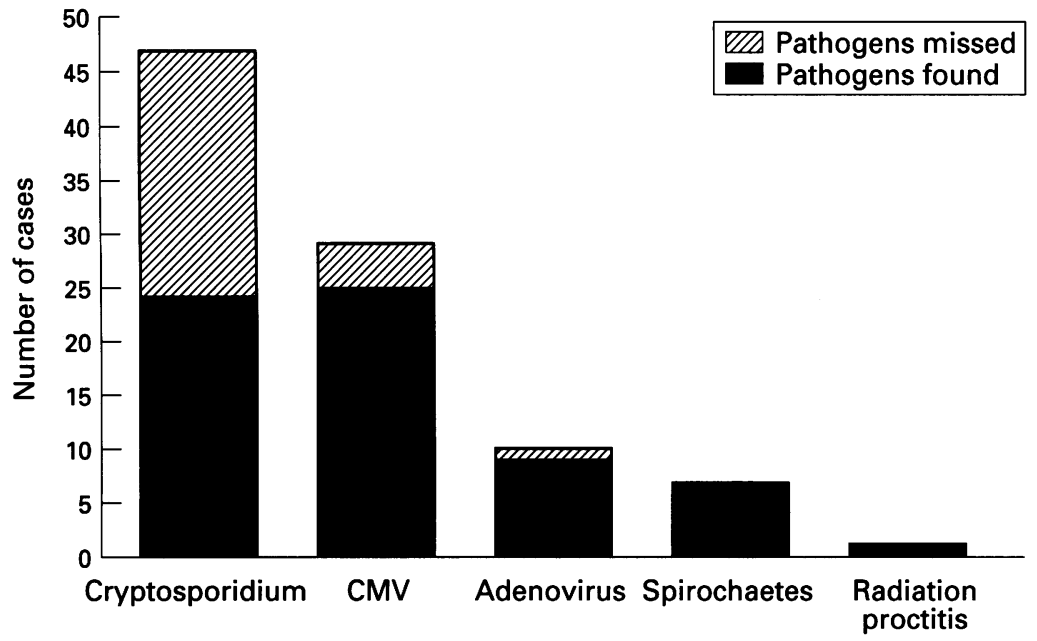

Figure 4: Histogram summarising the results of light microscopy of duodenal biopsy specimens in the diagnosis of various pathogens.

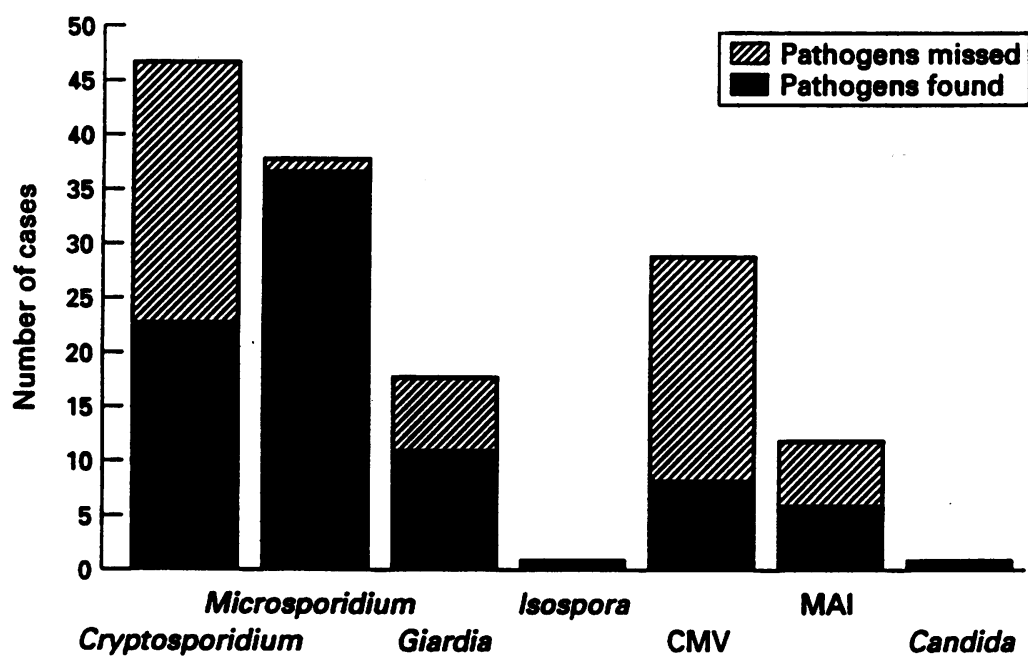

Figure 5: Histogram summarising the results of light microscopy of rectal biopsy specimens in the diagnosis of various pathogens.

TABLE IV Comparison of patients with and without a pathogen

\begin{tabular}{|c|c|c|c|}
\hline & Pathogen present & No pathogen & p Value \\
\hline Mean age $(y)$ & $37 \cdot 3$ & $34 \cdot 7$ & $0 \cdot 067^{\star}$ \\
\hline Mean weight (kg) & $62 \cdot 0$ & $65 \cdot 6$ & $0 \cdot 038^{\star}$ \\
\hline Mean total weight loss (kg) & $7 \cdot 3$ & $2 \cdot 7$ & $0 \cdot 001^{\star}$ \\
\hline Mean rate of weight loss (kg/month) & 2.9 & 0.8 & $>0.001^{\star}$ \\
\hline $\mathrm{BMI}\left(\mathrm{kg} / \mathrm{m}^{2}\right)$ & $20 \cdot 0$ & $20 \cdot 7$ & $0 \cdot 20^{\star}$ \\
\hline $\mathrm{CD} 4$ cells $/ \mu \mathrm{l}$ & 37 & 62 & $0.017^{\star}$ \\
\hline Time since AIDS diagnosed (months) & $7 \cdot 6$ & $10 \cdot 5$ & $0 \cdot 15 \dagger$ \\
\hline Mean stool frequency (per day) & 6 & 6 & $0 \cdot 85^{\star}$ \\
\hline Mean stool volume (ml) & 678 & 428 & $0 \cdot 01^{\star}$ \\
\hline Median serum vitamin B12 $(\mathrm{ng} / \mathrm{ml})$ & 200 & 315 & $0.003 \dagger$ \\
\hline Mean serum folate $(\mu \mathrm{g} / \mathrm{l})$ & $4 \cdot 5$ & $3 \cdot 4$ & $0.71+$ \\
\hline Median red cell folate $(\mathrm{mg} / \mathrm{ml})$ & 250 & 242 & $0.79 \dagger$ \\
\hline \multirow{2}{*}{$\begin{array}{l}\text { Xylose absorption: normal } \\
\text { reduced }\end{array}$} & 1 & 1 & $0 \cdot 11 \neq$ \\
\hline & 31 & 1 & \\
\hline Dicopac test: normal & 1 & 2 & $0.90 \ddagger$ \\
\hline malabsorption & 35 & 10 & \\
\hline Nausea: present & 45 & 13 & $0.85 \ddagger$ \\
\hline absent & 74 & 23 & \\
\hline Vomiting: present & 27 & 6 & $0.44 \ddagger$ \\
\hline absent & 92 & 30 & \\
\hline Incontinence: present & 40 & 13 & $0.78 \ddagger$ \\
\hline absent & 79 & 23 & \\
\hline Blood in the stool: present & 6 & 2 & $0.59 \ddagger$ \\
\hline absent & 113 & 34 & \\
\hline Mucus in the stool: present & 17 & 5 & $0.95 \ddagger$ \\
\hline absent & 102 & 31 & \\
\hline
\end{tabular}

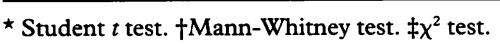

duodenal biopsy. Electron microscopy was less sensitive than light microscopy and is not necessary for routine use.

None of the investigations we examined identified more than $50 \%$ of pathogens when used alone. Therefore a combination of investigations is needed to make the correct diagnosis in patients presenting with diarrhoea. In clinical practice a stepwise diagnostic approach is often used, with less invasive investigations first (stool analysis) reserving more invasive tests (gut biopsy) for those without a pathogen in the stools. This is particularly likely when patients are initially seen by primary care physicians without immediate access to sigmoidoscopy and endoscopy. However we have shown that this results in pathogens being missed, whether the aim is to identify all potential pathogens or just those for which a specific treatment is available. Thus we would recommend that all HIV positive people with a CD4 count of less than $200 / \mu 1$ should have at least three stools analysed and light microscopy of duodenal and rectal biopsies. There is a high rate of acceptability of such intensive investigations to both patients and referring physicians: only $13 \%$ of those meeting the inclusion criteria of this study failed to complete investigations.

This clearly has important workload implications for gastroenterologists and pathologists, but it should be emphasised that this protocol only applies to those HIV positive patients with a CD4 count of less than $200 / \mu 1$ and chronic diarrhoea; our previous studies have suggested that less intensive investigation is appropriate for less immunocompromised patients or those with acute diarrhoea.

We thank the following for their valuable contributions to this project: Dr D Shanson and the Microbiology Department of the Westminster Hospital, London, for analysis of the stool specimens and blood cultures. Dr D Ellis and Mr DG Tovey of the Electron microscopy Department of the London School of Hygiene and Tropical Medicine, fo electron microscopy. Professor EU Canning and Dr W Hollister of the Parasitology Department, Imperial College, London, for examination of the small bowel impression smears.

TABLE V Comparison of patients with and without a small bowel pathogen

\begin{tabular}{|c|c|c|}
\hline & \multicolumn{2}{|c|}{ Small bowel pathogen } \\
\hline & Present & Absent \\
\hline $\begin{aligned} \text { Stool volume } & <500 \mathrm{ml} \\
& \geqslant 500 \mathrm{ml} \\
& <1000 \mathrm{ml} \\
& \geqslant 1000 \mathrm{ml}\end{aligned}$ & $\begin{array}{r}4 \\
45 \\
26 \\
23\end{array}$ & $\begin{array}{l}27 p<0.0001 \\
27 \\
46 p<0.001 \\
8\end{array}$ \\
\hline $\begin{array}{l}\text { Xylose absorption test } \\
\text { normal } \\
\text { abnormal }\end{array}$ & $\begin{array}{r}0 \\
22\end{array}$ & $\underset{10}{2 p=0 \cdot 11}$ \\
\hline $\begin{array}{l}\text { Dicopac (Schilling) test } \\
\text { normal } \\
\text { abnormal } \\
\text { Weight loss }<5 \mathrm{~kg} \\
\quad \geqslant 5 \mathrm{~kg}\end{array}$ & $\begin{array}{r}0 \\
32 \\
34 \\
28\end{array}$ & $\begin{array}{l}3 p=0 \cdot 06 \\
19 \\
63 p=0 \cdot 10 \\
30\end{array}$ \\
\hline
\end{tabular}
Small bowel pathogen is defined as identification of an
organism in duodenal or jejunal biopsy specimens examined by any method. 
TABLE VI Probability of identifying the cause of diarrhoea with different sequences of investigation (decision tree analysis)

\begin{tabular}{|c|c|c|c|c|c|c|c|c|c|c|c|c|}
\hline \multirow{3}{*}{$\begin{array}{l}1 \text { st } \\
2 \text { nd } \\
3 \text { rd }\end{array}$} & \multicolumn{4}{|c|}{ One stool } & \multicolumn{4}{|c|}{ Three stools } & \multicolumn{4}{|c|}{ Six stools } \\
\hline & Nil & $\mathrm{RBx}$ & OGD & Both & Nil & $\mathrm{RBx}$ & OGD & Both & Nil & $\mathrm{RBx}$ & OGD & Both \\
\hline & Nil & OGD & $\mathrm{RBx}$ & Nil & Nil & OGD & $\mathrm{RBx}$ & Nil & Nil & OGD & $\mathrm{RBx}$ & Nil \\
\hline All causes & $0 \cdot 186$ & 0.520 & 0.548 & 0.665 & 0.357 & 0.649 & 0.684 & 0.719 & 0.417 & 0.683 & 0.683 & 0.724 \\
\hline Treatable conditions & $0 \cdot 173$ & 0.403 & 0.481 & 0.500 & 0.357 & 0.591 & 0.602 & 0.663 & 0.388 & 0.612 & 0.582 & 0.612 \\
\hline Definite pathogens & $0 \cdot 200$ & 0.538 & 0.618 & 0.650 & $0 \cdot 388$ & 0.700 & 0.756 & 0.763 & 0.456 & 0.725 & 0.763 & 0.775 \\
\hline Treatable definite pathogens & $0 \cdot 158$ & 0.461 & 0.513 & 0.513 & $0 \cdot 368$ & 0.605 & 0.671 & 0.684 & 0.395 & 0.632 & 0.645 & 0.645 \\
\hline
\end{tabular}

RBx: rectal biopsy, OGD; oesophagogastroduodenoscopy with duodenal biopsy for light microscopy and aspiration of duodenal fluid; Both: sigmoidoscopy and rectal biopsy and OGD performed at the same visit. All causes include all the possible causes of diarrhoea in the cohort studied, including those not found on initial investigations. Definite pathogens and treatable pathogens are as defined in Table IV. The treatable conditions also includes the non-infectious causes of diarrhoea given in Table IV.

1 Malebranche R, Arnoux E, Guérin JM, Pierre GD, Laroche AC, Péan-Guichard C, et al. Acquired immunodeficiency syndrome with severe gastrointestinal manifestations in Haiti. Lancet 1983; ii: 873-7.

2 Dworkin B, Wormser GP, Rosenthal WS, Heier SK, Braunstein $\mathrm{M}$, Weiss $\mathrm{L}$, et al. Gastrointestinal manifestations of the acquired immunodeficiency synmanifestations of the acquired immunodeficiency syn-
drome: a review of 22 cases. Am $\mathcal{F}$ Gastroenterol 1985; 80: drome:

3 Girard PM, Marche C, Maslo C, Rene E, Leport J, Matheron S, et al. Digestive manifestations in acquired immunodeficiency disease. Ann Med Intern 1987; 138: 411-5 (in French)

4 Colebunders R, Francis H, Mann JM, Bila KM, Izaley L, Kimputu L, et al. Persistent diarrhoea strongly associated with HIV infection in Kinshasa, Zaire. Am $\mathcal{F}$ Gastroenterol 1987; 82: 859-64

5 Sewankambo N, Mugerwa RD, Goodgame R, Carswll JW, Moody A, Lloyd G, et al. Enteropathic AIDS in Uganda. An endoscopic, histological and microbiological study. AIDS 1987; 1: 9-13.

6 Antony MA, Brandt LJ, Klein RS, Bernstein LH. Infectious diarrhoea in patients with AIDS. Dig Dis Sci 1988; 9: 1141-6.

7 Colebunders R, Lusakamuni K, Nelson AM, Gigase P, Lebughe I, Van Marck E, et al. Persistent diarrhoea in Zairian AIDS patients: an endoscopic and histological study. Gut 1988; 29: 1687-91.

8 Laughton BG, Druckman DA, Vernon A, Quinn TC, Polk $\mathrm{F}$, Modlin JF, et al. Prevalence of enteric pathogens in homosexual men with and without the acquired immune

9 Miró JMcy syndrome. Gastroenterology 1988; 94: 984-93. Infectious gastroenteritis with the acquired immunodeficiency syndrome (AIDS). (Letter.) Ann Intern Med 1988; 109: 342-3.

10 Smith PD, Janoff EN. Infectious diarrhoea in human immunodeficiency virus infection. Gastroenterol Clin North immunodeficiency virus

11 Connolly GM, Shanson DC, Hawkins DA, Harcourt Webster JN, Gazzard BG. Non-cryptosporidial diarrhoea in human immunodeficiency virus (HIV) infected patients. Gut 1989; 30: 195-200.

12 Lane GP, Lucas CR, Smallwood RA. The gastrointestinal and hepatic manifestations of the acquired immunodeficiency syndrome. Med $\mathcal{F}$ Aust 1989; 150: 139-43.

13 Rene E, Marche C, Regnier B, Saimot AG, Vilde JL, Perrone $C$, et al. Intestinal infections in patients with the Acquired Immune Deficiency Syndrome: a prospective study in 132 patients. Dig Dis Sci 1989; 34: 773-80.

14 Rolston KV, Rodriguez S, Hernandez M, Bodey GP. Diarrhoea in patients infected with the human Diarrhoea in patients infected with the hum
immunodeficiency virus. Am $\mathcal{F M e d} 1989 ; 86: 137-8$.

15 Conlon CP, Pinching AJ, Perera CU, Moody A, Luo NP, Lucas SB. HIV-related enteropathy in Zambia: clinical, microbiological and histological study. Am $\mathcal{F}$ Trop Med Hyg 1990; 42: 83-8.

16 Johanson JF, Sonnenberg A. Efficient management of diarrhoea in the acquired immunodeficiency syndrome (AIDS). A medical decision analysis. Ann Intern Med 1990; 112: 942-8.

17 Connolly GM, Dryden MS, Shanson DC, Gazzard BG. Cryptosporidial diarrhoea in AIDS and its treatment. Gut 1988; 29: 593-7.

18 Buhles WC, Mastre BJ, Tinker AJ, Strand V, Koretz SH and the Syntex Collaborative Ganciclovir Treatment Study
Group. Ganciclovir treatment of life and sightthreatening cytomegalovirus infection: experience in 314 immunocompromised patients. Rev Infect Dis 1988; 10 (supl 3): S495-504.
19 Dieterich DT, Chachoua, Lafleur F, Worrell C. Ganciclovir treatment of gastrointestinal infections caused by cytomegalovirus infection in patients with AIDS. Rev Infect Dis 1988; 10 (suppl 3): S532-7.

20 Dieterich DT, Rahmin M. Cytomegalovirus colitis in AIDS: presentation in 44 patients and a review of the literature. $\mathcal{f}$ Acquir Immunodef Synd 1991; 4 (suppl 1): literature.

21 Dieterich DT, Kotler DP, Busch DF, Crumpacker C, Du Mond C, Dearmand B, et al. Ganciclovir treatment of cytomegalovirus colitis in AIDS: a randomised doubleblind placebo-controlled multicenter study. F Infect Dis 1993; 167: 278-2.

22 Nelson MR, Connolly GM, Hawkins DA, Gazzard BG. Foscarnet in the treatment of cytomegalovirus infection of the esophagus and colon in patients with the acquired immune deficiency syndrome. Am f Gastroenterol 1991; 86: $876-81$.

23 Francis ND, Boylston AW, Roberts AHG, Parkin JM, Pinching AJ. Cytomegalovirus infection of the Pinching AJ. Cytomegalovirus infection of the
gastrointestinal tracts of patients infected with HIV-1 or gastrointestinal tracts of patients infected
AIDS. F Clin Pathol 1989; 42: 1055-64.

24 Maddox A, Francis N, Moss J, Blanshard C, Gazzard BG. Adenovirus infection of the large bowel in HIV positive patients. F Clin Pathol 1992; 45: 684-8.

25 Weber R, Bryan RT, Owen RL, Wilcox CM, Gorelkin L, Visvesara GS. Improved light-microscopical detection of microsporidia spores in stools and duodenal aspirates. $N$ Engl F Med 1992; 326: 161-6.

26 Van Gool R, Snijders F, Reiss P, Eeftinck Schattenkerk JKM, van den Bergh Weerman MA, Bartelsman JF, et al. Diagnosis of microsporidial infections in patients with HIV by a new fluorescence technique. $\mathcal{F}$ Clin Pathol 1993; 46: 694-9

27 Rene E, Durrbach A, Bouali R, Chevalier T, Geoffroy L Roze C, et al. Digestive infections during AIDS.
Diagnostic strategy and costs. Gastroenterology 1989; 96: Diagn

28 Connolly GM, Forbes A, Gazzard BG. The investigation of apparently pathogen-negative diarrhoea in patients infected with human immunodeficincy virus (HIV-1). Gut 1990; 31: 886-9.

29 Connolly GM, Forbes A, Gleeson JA, Gazzard BG. Value of barium enema and colonoscopy in HIV positive patients with diarrhoea. AIDS 1990; 4: 687-9.

30 Gazzard BG. Practical advice for the gastroenterologist dealing with symptomatic HIV disease. Gut 1990; 31: 733-5.

31 Mayer HB, Wanke CA. Diagnostic strategies in HIVinfected patients with diarrhoea. AIDS 1994; 8: infected

32 Blanshard C, Gazzard BG. The incidence and cause of transient and persisting diarrhoea in relationship to CD4 Gastroenterol Hepatol 1993; 5: 823-8.

33 Blanshard C, Jackson AM, Shanson DC, Francis N, Gazzard BG. Cryptosporidiosis in HIV-seropositive patients. $Q 7 M$ 1992; 85: 813-23.

34 Orenstein JM, Chiang J, Steinberg W, Smith P, Rotterdam $\mathrm{H}$, Kotler DP. Intestinal microsporidiosis as a cause of diarrhoea in HIV-infected patients: a report of 20 cases. Hum Pathol 1990; 21: 475-81.

35 Eeftinck Schatternkerk JKM, Van Gool T, Van Ketel RJ, Bartelsman JF, Kuiken CL, Terpstra WJ, et al. Clinical significance of small intestinal microsporidiosis in HIV-1 infected individuals. Lancet 1991; 337: 895-8

36 Floch JJ, Laroche R, Kadende P, Nkurunziza T, Mpfizi B. Parasites, etiologic agents of diarrhoeas in AIDS. Significance of duodenal fluid test (In French). Bull Soc Pathol Exot Filiales 1989; 82: 316-20. 